\title{
Deterioration Analysis and Consolidation Time Using Terzaghi 1-D Method and 3D Plaxis Modeling: A Case Study of the Tebing Tinggi Toll Road Development Project - Indrapura STA. $103+200$
}

\author{
Awal Mansur'1, Roesyanto², Rudi Iskandar² \\ ${ }^{1,2}$ Master of Civil Engineering, Faculty of Engineering, University of Sumatera Utara, Indonesia.
}

Corresponding Author: Awal Mansur

DOI: https://doi.org/10.52403/ijrr.20220224

\begin{abstract}
Land transportation has an important role in the transportation sector. Road infrastructure is growing rapidly to meet basic human needs which increasingly require rapid movement for distribution of basic needs and other logistics. Soil has the characteristics of a relatively low bearing capacity and relatively large compression and lasts a relatively long time. One of the factors that cause soft soil to have a low bearing capacity is having a high water content. The high level of compressibility in soft soils is caused by the high void ratio. The development of preloading and vertical drainage methods is also combined with the use of horizontal drainage. Preloading works to compress the subgrade. PVD (Prefebricate Vertical Drain) serves to accelerate the process of soil compaction. PHD (Prefebricate Horizontal Drain) works to drain pore water from the PVD in a horizontal direction to the outside of the embankment. Located on the Tebing Tinggi Toll Road Construction Project Kisaran (Phase 1), the Tebing Tinggi Inderapura Toll Road in zone 3 Sta $103+200$. The purpose of writing this thesis is to analyze the magnitude of the settlement and consolidation time using analytical methods and using modelling in PLAXIS 3D. Analyzing the effect of the smear zone due to PVD erection using a mandrel. Analyzing the effectiveness of using PHD as horizontal drainage. Knowing the pore water pressure that occurs. Comparing the results of PLAXIS 3D modelling with data settlement in
\end{abstract}

the field. The calculation of the consolidation settlement using the 1-dimensional Terzaghi method was obtained at $102,46 \mathrm{~mm}$. This result is relatively close to the conditions that occur in the field, where the decrease in the SP-132 settlement plate in the field is $103 \mathrm{~mm}$ and the decrease in Asaoka is $102 \mathrm{~mm}$. The consolidation time required when there is a decrease of $100 \mathrm{~mm}$ in PLAXIS 3D modelling with a smear zone effect is 243 days and without a smear, the zone effect is 240 days. The required consolidation time without the use of PHD is 242 days and the consolidation time from the data settlement plate 132 (SP-132) is 239 days. Calculation of settlement and consolidation time using PLAXIS 3D modelling by taking into account the effect of the smear zone gives results that are close to the situation in the field. From the results of the PLAXIS 3D modelling, it is found that the minimum pore water pressure occurs until the end of the stockpiling activity for 248 days. The use of PVD in combination with PHD is effectively applied in the field, indicated by the minimum pore water pressure that occurs is smaller than without using PHD. From the percentage of pore water pressure that occurs in the soil, $64,4 \%$ is greater by using PHD, meaning that the percentage of water that comes out is faster by using PHD.

Keywords: Preloading, PVD, PHD, consolidation, PLAXIS 3D 
Awal Mansur, Roesyanto, Rudi Iskandar. Deterioration analysis and consolidation time using Terzaghi $1-D$ method and 3D PLAXIS modeling: a case study of the Tebing Tinggi toll road development project -Indrapura STA. $103+200$.

\section{BACKGROUND}

Each construction is planned in such a way that it has a certain load and at a certain elevation which sometimes cannot be served by the existing soil conditions due to the soft soil characteristics, while the implementation of construction work is attempted to be complex with a fast target time so that the benefits can be immediately felt by the community at large. One of the factors that cause soft soil to have a low bearing capacity is that it has high water content.

To overcome the problems of developing transportation infrastructure on soft soils, several soil improvement methods are shown where for soft soil the available repair methods are preloading (with vertical drain), electroosmosis, vacuum consolidation, lightweight fill, stone column, jet grouting, lime columns, fracture grouting, ground freezing, vitrification, electrokinetic treatment and electroplating others.

Soil improvement method with preloading combined with PVD will speed up consolidation settlement time and compress the subgrade. Preloading carried out by stockpiling gradually reincreases water stress in soft soil which will slowly decrease followed by an increase in Effective stress which results in the carrying capacity of the soil increasing (Zhafirah and Amalia, 2019). In the last two decades, the use of PVD as a soil improvement method has been recognized as one of the most effective and efficient methods of assisting preloading in locations with thick soft soil deposits (Holtz et al.)

In planning for soil improvement, settlement analysis and consolidation time are needed, so that it can be estimated the amount of settlement that must be achieved up to ninety percent consolidation and the time required for the process.

The location reviewed in this thesis is the Design and Build of the Tebing Tinggi - Kisaran Toll Road (Phase 1) Inderapura Tebing Tinggi Toll Road in zone 3 (three) Sta $103+200$. In this thesis, the analysis is carried out using the finite element method with the help of the PLAXIS 3D program (three dimensions) to obtain the magnitude of the settlement and the time required for the consolidation process. The results of the 3D modelling will be compared so that the results that are closest to the field conditions are obtained. The model also takes into account the effect of smear zone due to PVD erection with a mandrel.

\section{Prefabricated Vertical Drain (PVD)}

PVD is a soil improvement method that accelerates the consolidation process by shortening the drainage path of pore water in soft soil layers, so that water can be dissipated quickly. The use of PVD maximizes the consolidation of the radial direction by placing high-permeability materials in the soil. A clearer explanation can be seen in the drawing of land subsidence with vertical drainage and without using vertical drainage concerning time as follows. In soil improvement with initial loading, the problem that arises is the length of the settlement process. This often occurs in soil layers that are quite deep and have low permeability. To speed up consolidation and save time for subsidence on soft soil, the method used is to create a vertical channel that has high permeability, namely vertical drainage.

\section{Prefabricated Horizontal Drain (PHD)}

Prefabricated Horizontal Drain (PHD) is a composite tape-shaped material consisting of a core and a jacket that are installed horizontally with a certain installation method that functions as a drain.

\section{Smear zone}

Rowe (1968) in Barimbing (2017) states "in the installation of PVD it is assumed that the properties of the surrounding soil do not change, but the installation of PVD slightly disturbs the soil, depending on the sensitivity of the soil". The PVD is inserted into the ground using a mandrel and a shoe is attached at the end. 
Awal Mansur, Roesyanto, Rudi Iskandar. Deterioration analysis and consolidation time using Terzaghi $1-D$ method and 3D PLAXIS modeling: a case study of the Tebing Tinggi toll road development project -Indrapura STA. $103+200$.

As a result of this installation, the soil layer punctured by the mandrel will be disturbed. This disturbance is called the smear effect. The smearing effect is the decrease in the value of the radial soil permeability coefficient (KR) due to the remoulding process during PVD installation (especially if it is used forcibly). The disturbance depends on the size and shape of the mandrel, the soil microfabric and the installation procedure. A possible solution is to reduce the cross-sectional area of the mandrel, but maintain the stiffness of the mandrel.

\section{Consolidation}

Barimbing (2017) states that "consolidation is a process of decreasing volume that occurs slowly in fully saturated soils with low permeability conditions due to partial drainage of pore water". This process continues until the excess pore water pressure caused by the increase in total stress is completely removed. Primary consolidation is the main component of consolidation and can be reasonably estimated. A general theory for consolidation, which incorporates threedimensional flow, is quite complex and is only used for solving very limited problems in geotechnical engineering. For most practical problem solving, it is sufficient to assume that seepage, deformation and strain in soils only occur in one direction, as onedimensional consolidation, namely in the vertical direction (one-dimensional consolidation).

\section{PLAXIS 3D Program}

PLAXIS is a computer application program based on the two-dimensional finite element method which is used specifically to analyze deformation and stability for various geotechnical applications, such as soil bearing capacity. This program applies an easy-to-use graphical interface method so that users can quickly create geometric and mesh models based on cross-sections of the conditions to be analyzed. This program consists of four subprograms, namely input, calculation, output, and curve. In general, PLAXIS 2D and PLAXIS 3D are not much different, it's just that PLAXIS 3D presents a threedimensional display with better calculations and easier work because more elements are produced and patterns formed from elements are more detailed and fully modelled, such as field conditions.

Hird et al. (1995) presented a large test of the smear zone effect due to PVD erection on the soil around the PVD which was carried out in several locations, namely Porto Tolle Embankment (Italy), Harlow Embankment (U.K), and Lok Ma Chau Embankment (Hong Kong). The smear zone effect was analyzed with 2 dimensions. In this study, a match was made between the theory and the realization of settlement, void ratio and consolidation that occurred in the three project locations. In the test procedure, changes in soil permeability are carried out at locations affected by the smear zone due to PVD erection using a mandrel. From the results of the study, it shows that there is a match between the formulation offered by the researcher and the realization that occurs in the field. These results are indicated by the values of settlement, consolidation and excess pore pressure that occur in the field which show similar results to those calculated by the formula offered by the author.

Binbin (2017) presents an evaluation of the effect of increasing preloading on the environment around the construction using the PLAXIS 3D modeling. As a result of the addition of the load and the condition of the subgrade underneath, there will be horizontal movement of the soil that affects the surrounding environment. In practice in the field, to determine the lateral movement of the soil, an inclinometer is installed at the embankment border, for this study the horizontal movement is monitored by drawing a perpendicular line along the depth of the soil at the embankment border. This monitoring process is carried out every time there is an additional preloading load. The results of this study showed an increase in 
Awal Mansur, Roesyanto, Rudi Iskandar. Deterioration analysis and consolidation time using Terzaghi $1-D$ method and 3D PLAXIS modeling: a case study of the Tebing Tinggi toll road development project -Indrapura STA. $103+200$.

the preloading load, it was found that the maximum horizontal displacement gradually increased. The maximum horizontal displacements at each stage are $5.5 \mathrm{~cm}, 11.1 \mathrm{~cm}$ and $27.5 \mathrm{~cm}$ and the direction is towards the outside of the embankment. The maximum value of horizontal displacement is at the surface of the embankment and the deeper the soil elevation, the smaller the horizontal displacement that occurs. Due to the surface drainage, the pore water pressure at the surface will immediately disappear.

\section{RESEARCH METHOD}

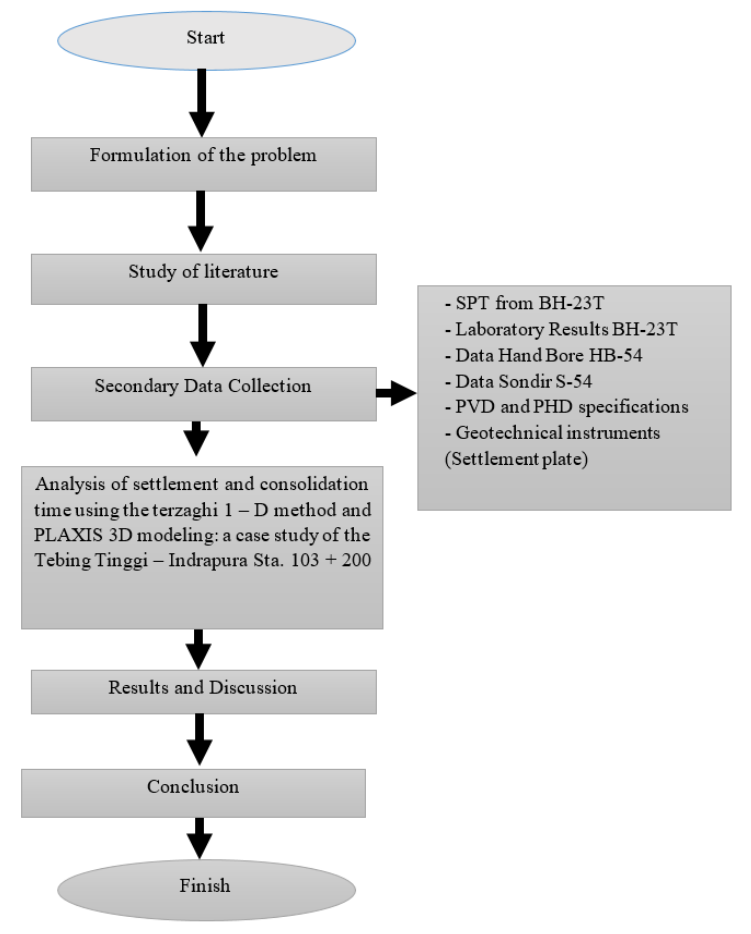

Figure 1. Research flow chart

In this study, the location chosen was the Tebing Tinggi - Kisaran Toll Road Development Project (phase 1) Tebing Tinggi - Indrapura Section (Sta. 86+250 to Sta. 106+650) which was carried out by PT. Hutama Karya (Persero), while for research and modeling data on the PLAXIS program taken at Sta. $103+200$. Data collection by running Layout work, Boring Log BH-1, Embankment material parameter data, PVD+PHD Specification, and Geotechnical instruments (settlement plate). The data needed are SPT (Standard Penetration Test), embankment soil parameters, PVD specifications and geotechnical instruments. Perform analysis of the decline and consolidation time using PLAXIS 3D with the data that has been obtained.

\section{RESULT AND DISCUSSION Consolidated Analysis with Triangle Pattern PVD Installation}

Actually, it refers to the conditions in the field, that the PVD used is installed in a triangular pattern and a mandrel tool is used to be able to enter the vertical drainage into the ground. The PVD was installed after the first embankment was $0.8 \mathrm{~m}$ high from the original soil and inserted $17.4 \mathrm{~m}$ deep so that the layer affected by the use of the mandrel.

\section{Calculation of smear zone effect}

Verification of vertical drain modeling is done by equivalating local vertical drains to be continuous (plane strain). From this calculation, the magnitude of the effect of the smear zone on the horizontal permeability coefficient of the soil will also be calculated. The test results using the formula method Hird et al large the effect of the smear zone on the vertical permeability coefficient of the soil $(\mathrm{kx})$ changes but the horizontal direction (ky) remains.

The value of $\mathrm{k}_{\mathrm{x}}$ in the table above represents the value of $\mathrm{k}_{\mathrm{x}}$ and $\mathrm{k}_{\mathrm{y}}$ in PLAXIS 3D modeling and $\mathrm{ky}$ in the table above represents the value of $\mathrm{kz}$ in PLAXIS 3D. This is because the above calculation is the calculation used for PLAXIS 2D input where there are only $\mathrm{x}$ and $\mathrm{y}$ axes which are interpreted as horizontal and vertical directions, while in PLAXIS 3D there are $\mathrm{x}$, $\mathrm{y}$ and $\mathrm{z}$ axes where $\mathrm{x}$ and $\mathrm{y}$ are interpreted as horizontal and $y$ axes are interpreted as the vertical axis. 
Awal Mansur, Roesyanto, Rudi Iskandar. Deterioration analysis and consolidation time using Terzaghi $1-D$ method and 3D PLAXIS modeling: a case study of the Tebing Tinggi toll road development project - Indrapura STA. $103+200$.

Table 1. BH-23T Material Properties table with smear zone effect

\begin{tabular}{|c|c|c|c|c|c|c|c|c|}
\hline URAIAN & UNIT & TIMBUNAN & $C L A Y$ & SANDYCLAY & SILTY SAND l & CLAY SAND & SILTY MEDIUM SAND & SILTY SAND 2 \\
\hline \begin{tabular}{|l|} 
Material Model \\
\end{tabular} & & Mohr Coulomb & Mohr Coulomb & Mohr Coulomb & Mohr Coulomb & Mohr Coulomb & Mohr Coulomb & Mohr Coulomb \\
\hline Kedalaman & $\mathrm{m}$ & 7,28 & $\begin{array}{l}0 \sim 0,8 \\
\end{array}$ & $0,8 \sim 4,5$ & $4,5 \sim 5,7$ & $5,7 \sim 18$ & $18 \sim 21$ & $21 \sim 28,5$ \\
\hline Drainage Type & & Drainage & Undrainage & Drainage & Undrainage & Drainage & Undrainage & Undrainage \\
\hline$\gamma_{\text {unsat }}$ & $\mathrm{KN} / \mathrm{m}^{3}$ & 2,157 & 9,17 & 9,17 & 9,17 & 9,30 & 9,06 & 9,06 \\
\hline$\gamma_{\text {sat }}$ & $\mathrm{KN} / \mathrm{m}^{3}$ & 9,69 & 21,78 & 21,78 & 21,78 & 23,33 & 22,93 & 22,93 \\
\hline $\mathrm{E}$ & $\mathrm{KN} / \mathrm{m}^{2}$ & 10000 & 2100 & 1800 & 1800 & 2100 & 5400 & 19800 \\
\hline $\mathrm{V}(\mathrm{nu})$ & & 0,30 & 0,35 & 0,25 & 0,25 & 0,35 & 0,30 & 0,35 \\
\hline $\mathrm{C}_{\mathrm{ref}}$ & $\mathrm{KN} / \mathrm{m}^{2}$ & 60,00 & 2,35 & 2,35 & 2,35 & 3,53 & 2,94 & 2,94 \\
\hline$\varphi$ (phi) & $\circ$ & 35,00 & 8,27 & 8,27 & 8,27 & 3,83 & 3,26 & 3,26 \\
\hline$\psi(\mathrm{psi})$ & $\circ$ & 0,00 & 0 & 0 & 0 & 0 & 0 & 0 \\
\hline $\mathrm{k}_{\mathrm{x}}, \mathrm{k}_{\mathrm{y}}$ & $\mathrm{m} /$ day & 1 & 0,0039 & 0,0039 & 0,0039 & 0,0013 & 0,0015 & 0,0015 \\
\hline $\mathrm{k}_{\mathrm{z}}$ & m/day & 1 & 0,0039 & 0,0039 & 0,0039 & 0,0013 & 0,0015 & 0,0015 \\
\hline \begin{tabular}{|l|} 
Nama Lapisan \\
\end{tabular} & \multicolumn{2}{|c|}{ Preloading } & 1 & 2 & 3 & 4 & 5 & 6 \\
\hline \multicolumn{9}{|c|}{ Setaelah Efek Smear Zone } \\
\hline URAIAN & \begin{tabular}{|l|} 
UNIT \\
\end{tabular} & TIMBUNAN & CLAY & SANDY CLAY & SILTY SAND 1 & CLAY SAND & SILTY MEDIUM SAND & SILTY SAND 2 \\
\hline Material Model & & Mohr Coulomb & Mohr Coulomb & Mohr Coulomb & Mohr Coulomb & Mohr Coulomb & Mohr Coulomb & Mohr Coulomb \\
\hline Kedalaman & $\mathrm{m}$ & 7,28 & $0 \sim 0,8$ & $0,8 \sim 4,5$ & $4,5 \sim 5,7$ & $5,7 \sim 18$ & $18 \sim 21$ & $21 \sim 28,5$ \\
\hline $\mathrm{k}_{\mathrm{x}}, \mathrm{k}_{\mathrm{y}}$ & $\mathrm{mm} / \mathrm{day}$ & 1 & 0,0004 & 0,0004 & 0,0004 & 0,0001 & 0,0002 & 0,0002 \\
\hline $\mathrm{k}_{\mathrm{z}}$ & mm.day & 1 & 0,0039 & 0,0039 & 0,0039 & 0,0013 & 0,0015 & 0,0015 \\
\hline
\end{tabular}

\section{Modeling and calculations on PLAXIS 3D}

Based on the results of analysis and modeling in the PLAXIS 3D program, it was found that:

Calculation of the consolidation settlement using the 1-dimensional Terzaghi method obtained $102.46 \mathrm{~mm}$. This result is relatively close to the conditions that occur in the field, where the decrease in the SP132 settlement plate in the field is $103 \mathrm{~mm}$ and the decrease in Asaoka is $102 \mathrm{~mm}$. There is a difference of $0.54 \mathrm{~mm}$ decrease from SP-132 and 0.46 from Asaoka, this difference is because the laboratory data do not represent the entire soil layer in the field, where for boring as deep as $28.5 \mathrm{~m}$ there are only 3 samples with the thickness of each sample. is 0.5 meters at a depth of $3.5 \mathrm{~m}-4 \mathrm{~m}, 7.5 \mathrm{~m}-8 \mathrm{~m}$ and $11.5 \mathrm{~m}-12 \mathrm{~m}$ The amount of consolidation that occurs using the finite element analysis method in PLAXIS 3D modeling using a coarse mesh type is compared to the calculation of the Terzaghi 1 Dimension method, so the percentage is obtained as shown in table below:

Table 2. Comparison of the derivation analysis of the Terzaghi method PLAXIS 3D coarse mesh type with data settlement plate SP132

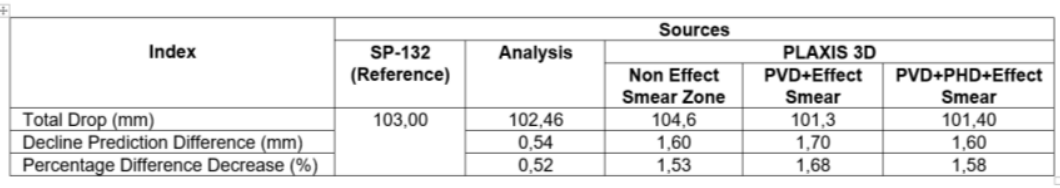

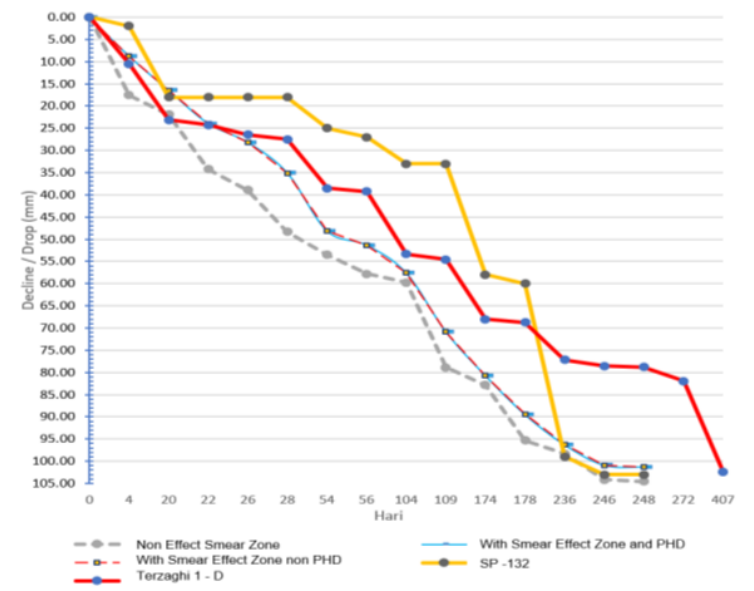

Figure 2. Graph of the relationship of decline and consolidation time
The graph of the relationship between the magnitude of the decline and consolidation time from the results of the PLAXIS 3D modeling with and without the smear zone effect, without the use of PHD and the field results from settlement plate 132 (SP-132) can be seen in Figure 4.28 where the length of time required for consolidation occurs when it occurs. The decrease of $100 \mathrm{~mm}$ in PLAXIS 3D modeling with smear zone effect was 243 days and without smear zone effect was 240 days. While the required consolidation time without the use of PHD is 242 days and the 
Awal Mansur, Roesyanto, Rudi Iskandar. Deterioration analysis and consolidation time using Terzaghi $1-D$ method and 3D PLAXIS modeling: a case study of the Tebing Tinggi toll road development project -Indrapura STA. $103+200$.

consolidation time from the data settlement plate 132 (SP-132) is 239 days, so it can be concluded that the calculation of settlement and consolidation time using PLAXIS 3D modeling by taking into account the effect of the smear zone gives good results approaching the situation in the field. The time required in the consolidation process using Plaxis modeling by taking into account the effect of the smear zone is longer than without taking into account the effect of the smear zone.

The amount of consolidation reduction that occurs in PLAXIS 3D modeling using a coarse mesh type compared to using PHD and without using PHD is obtained as a percentage as shown in Table below:

Table 3. Comparison of PLAXIS 3D coarse mesh type reduction with and without PHD

\begin{tabular}{|l|c|c|}
\hline \multirow{2}{*}{ Index } & \multicolumn{2}{|c|}{ PLAXIS 3D } \\
\cline { 3 - 3 } & PVD+PHD+Effect Smear & Non PHD \\
\hline Total Drop $(\mathrm{mm})$ & \multirow{2}{*}{101,4} & 101,3 \\
\hline Decline Prediction Difference $(\mathrm{mm})$ & & 0,10 \\
\hline Percentage Difference Decrease $(\%)$ & & 0,10 \\
\hline
\end{tabular}

From the results of the 3D PLAXIS modeling, it is found that the minimum pore water pressure that occurs until the end of the stockpiling activity is 248 days. The comparison of the minimum pore water pressure for modeling with the use of PHD, without PHD can be seen in Table below.

Table 4. Comparison of the minimum pore water pressure that occurs in the final consolidation phase
\begin{tabular}{|l|c|c|}
\hline \multicolumn{1}{|c|}{ Index } & \multicolumn{1}{|c|}{ PLAXIS 3D } \\
& PVD+PHD+Effect Smear & Non PHD \\
\hline Minimum pore water pressure $\left(\mathrm{kN} / \mathrm{m}^{2}\right)$ & \multirow{2}{*}{-0.0004340} & -0.0012070 \\
\hline Difference in pore water pressure $\left(\mathrm{kN} / \mathrm{m}^{2}\right)$ & & 0.000773 \\
\hline $\begin{array}{l}\text { Percentage Difference Minimum pore } \\
\text { water pressure }(\%)\end{array}$ & & 64,04 \\
\hline
\end{tabular}

From the results of Table 4 it is found that how effective is the use of PHD to help the consolidation process and the length of time for consolidation in the final consolidation to the minimum condition of excess pore pressure

This study shows that there are differences in the graph of the pattern of decline in monitoring results in the field compared to the PLAXIS model. This difference is due to the division of calculation phases in PLAXIS. In the PLAXIS program, the calculation phase is made of the increase in embankment height over several periods of time and in one phase of stockpiling it is calculated for a long time, while in field monitoring the settlement data collection is carried out periodically with a predetermined time even though the increase in embankment elevation is only slightly or even no increase embankment elevation. The more phase divisions and the shorter the calculation time, the more the resulting graph will be closer to the field monitoring graph.

\section{CONCLUSION}

The size of the consolidation settlement using the analytical method with the Terzaghi 1-dimensional formula obtained a decrease of $102.46 \mathrm{~mm}$, the PLAXIS 3D modeling without the smear zone effect used the coarse mesh type = $104.6 \mathrm{~mm}$, the PLAXIS 3D modeling with the smear zone effect used the coarse mesh type $=101.3 \mathrm{~mm}$ and PLAXIS 3D modeling with smear zone effect and without PHD using a coarse mesh type $=101.4 \mathrm{~mm}$. The consolidation time required when there is a decrease of $100 \mathrm{~mm}$ in PLAXIS 3D modeling with a smear zone effect is 243 days and without a smear zone effect is 240 days. The required consolidation time without the use of PHD is 242 days and the 
Awal Mansur, Roesyanto, Rudi Iskandar. Deterioration analysis and consolidation time using Terzaghi $1-D$ method and 3D PLAXIS modeling: a case study of the Tebing Tinggi toll road development project -Indrapura STA. $103+200$.

consolidation time from the data settlement plate 132 (SP-132) is 239 days. It can be concluded that the analytical calculations and PLAXIS 3D modeling are relatively close to the conditions that occur in the field, where the decrease in the SP-132 settlement plate in the field is $103 \mathrm{~mm}$. This difference is because laboratory data do not represent the entire soil layer in the field.

The effect of the smear zone on soil subsidence is different for each soil type, where in this study the values of $\mathrm{s}^{\prime}=2$ and $\mathrm{k}$ $=3$ have results that are close to the results of field observations. This shows that the diameter of the smear zone is 2 times the diameter of the mandrel and the horizontal permeability of the soil is 3 times less than the permeability of the original soil.

The use of PVD in combination with PHD is effectively applied in the field as a substitute for sand blankets, indicated by the minimum pore water pressure that occurs is smaller than without using PHD. From the percentage of pore water pressure that occurs in the soil, $64.4 \%$ is greater by using PHD, meaning that the percentage of water that comes out is faster by using PHD than without using PHD.

\section{Acknowledgement: None}

\section{Conflict of Interest: None}

\section{Source of Funding: None}

\section{REFERENCES}

1. AASHTO. (1929), Public Road Administration Classification System.

2. Asaoka, A. (1978), "Observational procedure of settlement prediction", Journal Soils and Foundations; 18(4):87101.

3. Barimbing, F. R. (2017), “Analisis Penurunan dan Waktu Konsolidasi Tanah Lunak Menggunakan Metode Preloading dan Pre Fabricated Vertical drain (Studi Kasus Proyek Pembangunan Jalan Bebas Hambatan Medan - Kualanamu Sta 35+950)". Skripsi Universitas Sumatera Utara
4. Barron, R. A. (1948), Consolidation of fine-grained soils by drain wells. Trans. ASCE, 113, 718-742.

5. Binbin, X. (2017), "Influence of Surcharge Preloading Improvement on Surrounding Environment Based on PLAXIS 3D", IOP Conference Series: Earth and Environmental Science, 100 (2017) 012108.

6. Bjerrum, L. (1967), Engineering geology of Norwegian normally-consolidated marine

7. clays as related to settlements of buildings, G'eotechnique 17 , No. 2: 81118.

8. Bowles J. E. (1993), Sifat - Sifat Fisis dan Geoteknis Tanah (Mekanika Tanah), Edisi kedua. Jakarta:Erlangga.

9. Carillo, N. (1942), Simple two - and three - dimensional cases in the theory of consolidation of soils. Journal of Mathematics and Physics, 21(1), 1-5.

10. Chai, J. C., Horpibulsuk, S., Shen, S., Carter, J. P. (2014), "Consolidation analysis of clayey deposits under vacuum pressure with horizontal drains", Journal of Geotextiles and Geomembranes 42 (2014) 437-444

11. Chu, J., Bo, M. W., and Choa, V. (2004), "Practical considerations for using vertical drains in soil improvement projects". Geotextiles and Geomembranes, 22, Issues 1-2, pp101117

12. Chunlin, L. (2013), “A Simplified Method for Prediction of Embankment Setlement in Clays", Journal of Rock Mechanics and Geotechnical Engineering 6 (2014) 61-66.

13. Craig R. F. (1991), Mekanika Tanah, Edisi Keempat. Jakarta: Erlangga.

14. Darwis, H. (2018), Dasar-dasar Mekanika Tanah. Yogyakarta : Pena Indis.

15. Das, B. M. (2006), Principles of Geotechnical Engineering Seventh Edition, Cengage Learning. Stamford.

16. Das, B. M. (1998), Mekanika Tanah 1 (Prinsip-prinsip Rekayasa Geoteknis), Diterjemahkan : Endah Noor, Indrasurya B Mochtar. Erlangga. Jakarta.

17. Das, B. M. (1998), Mekanika Tanah 2 (Prinsip-prinsip Rekayasa Geoteknis), 
Awal Mansur, Roesyanto, Rudi Iskandar. Deterioration analysis and consolidation time using Terzaghi $1-D$ method and 3D PLAXIS modeling: a case study of the Tebing Tinggi toll road development project -Indrapura STA. $103+200$.

Diterjemahkan : Endah Noor, Indrasurya B Mochtar. Erlangga. Jakarta.

18. Das, B. M. (2008), Advanced Soil Mechanics Third Edition, UK:British Library.

19. Esrig, M.I. (1968), "Pore pressures, consolidation and electro-kinetics". Journal of the Soil Mechanics and Foundation Engineering Division ASCE, 94, pp899- 921.

20. Hausmann, M.R. (1990), Engineering Principles of Ground Modification, McGraw-Hill

21. Hansbo, S. (1979), Consolidation of Clay by Band-Shapped Prefabricated Drains. Ground engineering, july, Vol.12, No.5.

22. Hansbo, S. (1981), Consolidation of finegrained soils by Prefabricated Drains, Proceedings 10th International Conference on Soil Mechanics and Foundation Engineering, Stockholm, Vol. 3, PP.667-682.1981.

23. Hansbo, S. (1987), Design Aspects of Vertical Drains and Lime Colomn Installations. Southeast Asian Geotechnical Conference.

24. Hardiyatmo, H.C. (2008), Geosintetik untuk Rekayasa Jalan Raya Perencangan dan Aplikasi edisi pertama. Yogyakarta: Gajah Mada University Press.

25. Hayati, T. (2018), Analisis Pengaruh Smear Zone pada Penurunan dan Waktu Konsolidasi dengan Plaxis 2D dan 3D. Media Komunikasi Teknik Sipil.

26. Hird, C. C., Pyrah, I. C., Russel, D. dan Cinicioglu, F. (1995), Modelling the Effect of Vertical drains in Twodimensional finite element analyses of embankments on soft ground. Canadian Geotecnical Journal DOI:10.1139/195077.

27. Holtz, R. D. dan Kovacs, W. D. (1981), An Introduction to Geotechnical Engineering. Prentice-Hall, Englewood Cliffs, New Jersey.

28. Indraratna. B., Member, ASCE, dan Redana, I.W. (1997), "Plane strain Modeling of Smear zone Effect Associated with Vertical drains.", Jurnal of Geotecnical and Geoenviromental Egineering, Vol. 123, No. 5.
29. Iskandar, R. (2018), Teknik Perbaikan Tanah dengan Menggunakan PVD dan Preloading. Medan : USU Press.

30. Jamiolkowski, M., Lancellotta, R. dan Wolski, W. (1983), "Precompression and Speeding Up", In Proceedings of 8th European Conference on Soil Mechanics and Foundation, Helsinki, Finland, 3, 1201-1206.

31. Look, B. G. (2007), Handbook of Geotechnical Investigation and Design Tables. Taylor \& Francis/Balkema, Netherlands.

32. Menon, R. A., Bhasi, A. (2020), "Numerical Investigation of Consolidation Induced by Prefabricated Horizontal Drains (PHD) in Clayey Deposits", Journal of Geotech Geol Eng https://doi.org/10.1007/s10706-02001612-y

33. Meyerhof, G. G. (1956), "Penetration tests and bearing capacity of cohesionless soils", ASCEJ Soil Mech Found Div 82:866- 1019.

34. Meyerhof, G. G. (1976), "Bearing capacity and settlement of pile foundations", Journal Geotech Eng Div 102:195-228.

35. Muller R. and Larsson S. (2013), Aspects on the modelling of smear zones around vertical drains. Proceedings of the 18th International Conference on Soil Mechanics and Geotechnical Engineering, Paris 2013

36. Nawir, H., Dayu, A., Fatimatuzahro, R. dan Pamuji, M. D. (2012), "Prediksi Penurunan Tanah Menggunakan Prosedur Observasi Asaoka, Studi Kasus : Timbunan di Bontang, Kalimantan Timur", Jurnal Teoretis dan Terapan Bidang Rekayasa Sipil, ISSN 0853-2982.

37. Ohoimas, M., Y., Hamdhan, I., N. (2015), Analisis Konsolidasi dengan Menggunakan Metode Preloading dan Vertical drain pada Areal Reklamasi Proyek Pengembangan Pelabuhan Belawan Tahap II. Jurnal Institut Teknologi Nasional.

38. PLAXIS V.8.2 Manual Latihan. https://www.PLAXIS.com/upload/

product manuals /PLAXIS82 Indonesian_2-Acuan.pdf 
Awal Mansur, Roesyanto, Rudi Iskandar. Deterioration analysis and consolidation time using Terzaghi $1-D$ method and 3D PLAXIS modeling: a case study of the Tebing Tinggi toll road development project -Indrapura STA. $103+200$.

39. Rixner, J.J.,Kraemer, S.R \& Smith, A. D. (1986), "Prefabricated vertical drains. 1(Engng Guidelines). FHWA (Federal Highway Administration) Report no. FHWARD-86-168. Washington DC, USA.

40. Roesyanto, Iskandar, R., Silalahi, S. A. dan Fadliansyah (2018), "Soil Setlement Analysis in Soft Soil by Using Preloading System and Prefabricated Vertical draining Runway of Kualanamu Airport", IOP Conf. Series: Materials Science and Engineering.

41. Sosrodarsono, S., Nakazawa, K. (1981), Mekanika Tanah \& Teknik Pondasi. Jakarta : PT. Pradnya Paramita.

42. Stapelfeldt, T. (2006), "Preloading and Vertical Drains", Geotechnics Seminar of Helsinky University of Technology.

43. Terzaghi, K. (1925), Principles of Soil Mechanics IV. Settlement and

consolidation of clay. Engineering NewsRecord 1925;95:874-8.

44. [USDA] United State Departement of Agriculture. (2010), USDA National Nutrient Database for Standart Reference.

45. Zhafirah, A., Amalia D. (2019), Perencanaan Preloading Dengan Penggunaan Prefabricated Vertical drain untuk Perbaikan Tanah Lunak Pada Jalan Tol Pejagan-Pemalang. Jurnal Politeknik Negeri Bandung Vol. 21, No.1, Maret 2019.

How to cite this article: Awal Mansur, Roesyanto, Rudi Iskandar. Deterioration analysis and consolidation time using Terzaghi 1-D method and 3D PLAXIS modeling: a case study of the Tebing Tinggi Toll road development project - indrapura STA. $103+200$. International Journal of Research and Review. 2022; 9(2): 165-173. DOI: https://doi.org/10.52403/ijrr.20220224 